passes being heated anct illuminated by the comet; and that the other phenomena are also clue to the ether.

I rely that you will do me the justice to allow space for me to remind your readers that the theories which Prof. Reynolds so emplatically calls his, were propounded and published by me sixteen years ago, and noticed by most of the press throughout the world.

The following quotation from my pamphlet (now out of print) will enable your rearlers to judge of the correctness of these slatements :-

"It was noticed, in reference to 'Biela's comets,' that the smaller one, which I call the tertiary comet, and which travelled in a separate or distinct orbit, that a kind of reir; or stream of light, joined the two heads, the stream of light being larger as it approached the head of the larger comet. This stream of light, I think, proves most satisfactorily that the 'tails' of comets are nothing more than the illuminated or heated mudium through which the cumets pass. The cylindrical appearance which these 'tails' sometimes present, I believe is occasioned by the rotary motion of the comets (or infant worlds) on their respective axes. The increased number of 'tails' to a comet is occasioned by the interposition of one or more seconclary or tertiary comets, intercepting the 'tail' of the superior budy, the direction of which "tails" would be determined by the position of the said intercepting bodies, aod the variety of appearance in connection with the point from which they were viewed," \&c.

$$
\text { Bayswater, Jan. } 9
$$

$$
\text { J. BEDFORD, Ph.D. }
$$

\section{The Artificial Introduction of Plants}

THE remarks on page I 42 of your number of December 22, on the proposal of the Manchester Field Club to introduce plants foreign to the district, ought to be printed in red letters. The geographical distribution of plants is not the least interesting branch of botanical study, and is, besides, important in its bearings upon other natural sciences, such as geology and meteorology, and as such has formed the subject of laborious and intelligent research among various eminent naturalists.

Amateur botanists can carry on their favourite pursuit in two widely-different ways : they can play at science, and so amuse themselves to their own satisfaction, may be, but with little advantage to what they propose to admire, or they may patiently and conscientiously work and observe within their own sphere of research, and thus be able to render, as occasion serves, very real service to science at large, more, perhaps, than they are aware of at the time, and certainly to earn very genuine pleasure for themselves.

Not that I mean to insinuate that the Manchester Club are playing at science, but I warmly agree with your remarks that a mistake is being made by them in this respect. The instance is not a solitary one, even in my limited experience. Not long ago I found myself protesting against the notion of an amateur botanist (in England), who was endeavouring to introduce a species into a new locality. This is about as detrimental a proceeding in its way as that of the wanton eradication of a species from a neighbourhood.

I write con anore, for I happen to live and botanise in a part of Europe lying off the line of railways, therefore little visited, but possessing an interesting and somewhat peculiar fora, and am not unfrequently applied to by eminent botanists for information as to the real existence in the district of plants alleged with more or less of truth to be indigenous here.

Fiume, Austria

An Amateur Botanist

\section{Science Teaching}

IN an article in NATURE, December 29, I870, on "Science at School Boards," the teaching capabilities of this country appear to me to be under-rated ; I refer especially to the following passage :- "We would advise that some attempt be made to teach some guantum of Natural Science somehow. The present masters will probably be utterly ignorant of any branch of Science!"

If such is the fact, I would ask what have the training-schools been doing for years past? Most of these schools have university men as teachers, or men who have nbtained a lectureship; and surely they have turned out students of two years' residence, capable of teaching one or more of the elementary branches named by the writer of the axticle referred to.
Does Dr. Lankester really think that the majority of the trained certificated masters of this country are incompetent to teach elementary physical geography? Many of these masters possess, I believe, a certificate for teaching Science, in virtue of having passed an examination under the Science and Art Department; and surely the examiners employed by the Depart ment are such men as even Dr. Lankester would not ignore.

I feel confident that sofar as teachers are concerned the matter is not so bad as Dr. Lankester imagines. The Revised Code checked all science teaching in elementary schools, but only let the Committee of Council accede to the appeal now made, and they will find plenty of masters able and desirous of teaching the elements of Science in our elementary schools.

There are two obstacles to be overcome before good results can be obtained. There must be better and ampler teaching power employed in our schools, so as to give the master the opportunity to carry out consecutive teaching; and then people generally must be made aware of the importance of Science to the artizan class, parents must be taught to appreciate the efforts made for their children. I will venture to say that more than lialf the work of the best teachers of this country is neutralised by the indifference or ignorance of parents.

Wisbech, Jan 3

Samuel H. Mili.er

\section{The Frost}

I REMARK in the "Notes" of your last number, it is stated that "the lowest temperature at Blackheath was $153^{\circ} \mathrm{F}$., on the night of the 24th December."

Now, assuming the correctness of the instrument from which this observation was taken, the locality must be much more protected from frost than that in which I reside. I have two good registering thermometers placed in a N.E. aspect, at about twenty-five or thirty feet from the ground-the one an upright mercury (Beck, Cornkill), the other a horizontal spirit tule (Hughes, Fenchurch Street), and the reaclings, which correspond exactly, were as follows :-

On the night of $23-24$ Dec. $x 2^{\circ} \mathrm{F}$., and at 7 A.M. On the $24^{\text {th }}$

14. The maximum temperature (about noon) on the $24^{\circ}$ th was $24^{\circ}$, and at II P.M. the mercury had dropped to $x 6^{\circ}$.

On the night of the $24-25$ th the minimum was $9^{\circ} \mathrm{F}$, at which point the register stood as late as $7 \mathrm{~A} . \mathrm{M}$. on the $25 \mathrm{th}$, and even at IO A.M. it had only risen $x^{\circ}\left(10^{\circ} \mathrm{F}\right.$.)

I send you these observations, which I believe to be very correct, as they may be of some interest to meteorologists in our neighbourhood.

Blackheath, Jan. 9

JOHN CAREY

[It will be seen that these figures correspond very nearly with those given in our "Notes" this week. -ED.]

ON Sunday morning, Ist inst., a standard terrestrial radiation thermometer (exposed here on the previous evening) registered the unusual low temperature of $6 \cdot 3{ }^{\circ} \mathrm{F}$. or $25^{\circ} 7^{\circ}$ below the freezing point.

The instrument was placed a few inches above snow covered grass on a gravelly soil, and exposed to nearly the whole sky.

Temporary Meteorological Observatory, JOHN JAMES HALL

Fulwell, Twickenbam, Jan 5

\section{Sharks announcing their own Capture}

Lieut. C. H. TAylor, of H.M.S. Cossack, in his Remarkbook for $1869-70$, alludes to the following ingenious mode of making sharks announce their own capture, It appears that the island of Johanna, at the north end of the Mozambique Channel, is frequently visited by numerous sharks, whose fiesh is esteemed as an article of food by the natives, who also prize the skin and oil for domestic or commercial purposes.

The Johamna men, however, being too lazy to fish in what might be termed a legitimate manner, have recourse to floating traps, with line, hook, and bait, and supporting above water a pole and basket. A bight of the line near the raft is attached to a bolt or toggle, which, when in place, keeps the pole in an upright position, but the moment a strain is brcught on the line by the fish being hooked, the tccole is withdramn, causing the pole and basket to fall, which is a signal to the people on shore that the prey awaits their coming.

Hydrographic Office, Admiralty
G. F. MCDOUGABL 